\title{
Federalism as a Public Good
}

JENNA BEDNAR ${ }^{1}$

Department of Political Science, University of Michigan, USA

Abstract. This paper suggests that stabilizing federalism is like solving a public good provision problem. It reviews results in the public good provision literature that are relevant for federalism, and discusses the implications of these results for the institutional design of federalism.

JEL classification: H110, H770, P160

Key words: Intergovernmental relations, government performance, institutional design

Federalism now reaches to all corners of the globe, yet in political science we still lack a basic understanding of how to design institutions to maximize the chances that a federation will be successful. We write federal constitutions without knowing what might best be included to maximize the possibility of peace and prosperity. We advocate adoption of the constitutional architecture of successful federations, a policy that will meet with diminishing success as federalism moves from the western developed world to cultures and contexts that are quite different. Some adopt federal constitutions despite our relative ignorance, such as Russia, Bosnia, South Africa, and Iraq. Others hesitate, lacking confidence in their ability to engineer a successful federation. For example, Afghanistan would have been a natural case for federation, given its regions' histories of political independence, but Afghani constitutional planners and their consultants rejected a federal solution, not knowing how to build a federation strong enough to resist the peripheralizing forces of aggressive, competitive provinces. And in Argentina, the federal government is pleading for another restructuring of its debt repayment scheme, despite being unable to find a remedy for the root cause of its fiscal misfortune: provinces who have little incentive to balance their books, despite the ill effects for the national economy.

What makes a federation successful, robust? Is it historical accident, cultural influences, or the institutional elements in a constitution that affect its success? If institutions matter, have we fully explored their significance? In this paper I advocate a new approach to the study of federalism that describes federalism as a public good provision problem. The implication of this description is that we are able to enlist our understanding of how public good provision problems may be resolved to the design of federalism. However, these results must be modified to fit the particular challenges that federalism presents. This paper focuses on how a network of institutions, complementary in their functional capacity, makes federations productive. In so doing, the project departs from existing studies, which have focused on the effect of the existence of particular institutions - often considered in isolation - on the longevity of the federation or distributional aspects of it. 
It is not the welfare of the federal government that concerns us; the government is a means, designed to improve the lives of its citizens. Therefore the lifespan of the union is only an indirect proxy; it can reflect government performance, but governments can endure for other reasons as well: consider the longevity of the authoritarian regimes in Cuba, China, and the USSR. Our real interest is how well the government serves its people, how well it performs its designated tasks. This is what we mean by robustness.

Robustness focuses attention on the connection between the federations' organizational architecture and its performance. The theory has its roots in the public good provision literature, which I have expanded to accommodate the complexities of federalism. Lessons learned from these models cause us to focus on complementarities between the functional capacities of institutions, rather than the existence of particular institutions. In this manner, constitutions may be locally adapted to fit cultural and environmental context, while meeting the needs of a robust federation.

The paper proceeds as follows. I first define federalism and robustness more completely. In the second section, I develop the reasons for forming a federation, each which displays characteristics of a classic public good provision problem. In the third section I review results in the public good provision literature relevant to federalism, and in the fourth, I discuss how these results help us to understand the institutional design of federalism. The fifth section concludes.

\section{Definitions}

Studies of successful federations to date have been plagued by definitional problems, leaving (frustratingly, improbably) both the subject and the dependent variable undefined. In this Section I define both subject and dependent variable.

\subsection{Federalism}

It is not a straightforward task to list all federations in existence. Definitions are often too vague to enable objective coding. ${ }^{2}$ Many works eschew formal definitions altogether, arguing that federalism has an intuitive quality that formally cannot be defined but is recognizable. Elazar (1987) argues that federalism is a process as well as a structure (see also Beer 1993 and Ostrom 1991). Therefore, most political theorists agree that a polity must be federal in practice as well as form, but defining federal practice is elusive. It quickly degenerates into a youknow-it-when-you-see-it science, and the variation in the lists of federations manifests this controversy. While many agree on about a dozen cases of federalism, including the United States, Canada, Argentina, and Germany, another two to three dozen cases are contentious: Spain, Italy, Venezuela, the USSR, China, Great Britain, and the European Union.

In rejecting a structural definition of federalism because it fails to guarantee federal practice, we may be skipping over a clue that could help us to identify what makes a 
federation successful. Another word for practice is behavior, and institutional theory helps us to appreciate the role that institutions play in affecting behavior. We may examine how the institutions that surround a federal structure compel behavior that is federal. Therefore that it is important to include as federal all cases that meet the structural definition of federalism, rather than weeding out those that don't "feel" federal because they are not federal in practice. If we leave them out, then we are studying only those that are successful to some degree. It remains important to study those that never got off the ground as well.

The following three structural features define a federation:

Geopolitical Division. The polity's territory is divided up into mutually exclusive states (or provinces, lander, etc). The existence of each state is constitutionally recognized and may not be unilaterally abolished.

Independence. The states and federal government are independent of one another. In general, this independence is established constitutionally through electoral independence, where each government is held accountable to its constituents, although non-democratic forms of independence may be available.

Direct Governance. Authority is shared between the state and the national governments, which each govern their citizens directly, so that each citizen is governed by two authorities. Each level of government is sovereign in at least one policy realm. This policy sovereignty is constitutionally declared.

The definition stresses constitutional declarations because a constitution can create common expectations about the way the government should work (Hardin 1989). But declarations are not guarantees. The question becomes, under what conditions will expectations meet reality? And since the solution must be self-enforcing, we want to ask, under what conditions will the governing units of the federation cause these expectations to be realized?

Geopolitical division excludes other organizational forms, such as consociational government, where authority is divided by policy domain. It also excludes the many polities that have delegated responsibilities to lower levels of government; this administrative decentralization may be economically efficient, but the lower level enjoys its powers as long as it is politically expedient for the national government to permit them. If the national government may recentralize unilaterally, the polity does not meet the third criterion and is not federal. (One such example is most municipal governments in the United States, who are chartered by the state governments.) The second and third criteria establish the independence of the governments. In the second criterion, one level of government does not appoint all political leadership of the other level. If inter-level appointment occurs (for example, U.S. Senators prior to the 17th Amendment), then other political leaders derived entirely from the state (or federal) selection method must be able to veto the decisions made by the appointee. The third criterion, direct governance, excludes governing structures where the national level operates as an oversight board or coordinates state activity, such as confederations. 
Of course not all structural conditions are in practical evidence. This confusion underscores the connection between maintaining the structural features and a federation's performance.

\subsection{Robustness}

As described above, a second difficulty in prior studies is the specification of the dependent variable. Many studies focused on the variable stability. Stability is both difficult to measure ${ }^{3}$ and misplaces the focus. Stability emphasizes federalism as ends - the existence of federalism - rather than federalism as means - its performance. Governments are tools to satisfy goals set by the constitutional designers, goals that may be updated according to changing demands. How well do federations achieve these goals? What institutional systems enable federal structures to perform well? To answer these questions, this study shifts the dependent variable from existence to performance, to emphasize robustness. In the study of robustness, as opposed to stability, we are interested in how a system maintains features and functionalities in the face of change and perturbations (Jen 2002).

Our primary concern is how federal systems perform in the real world, under varied, changing circumstances. A federal system must be flexible and responsive, but not overreact to economic, political, and social challenges. This contrasts with a federation in stasis, that cannot respond, and whose citizens suffer. Persistent strong performance will therefore be evidence not of stability but of robustness. And robustness, not stability, should be a better predictor of longevity for those interested in regime duration.

In the section that follows, I describe the functionalities that guarantee robustness in detail. I identify opportunism as the chief perturbation that threatens the performance of federations. A robust federation minimizes opportunism to maximize productivity. For empirical verification, since opportunism is not observable, and not measurable, we define a robust federation as one that performs well.

\section{Objectives}

Federalism may provide a variety of benefits; it is populations that seek one or more of these benefits who choose federalism as their governmental form. Federalism's performance at meeting these objectives determines its robustness. The potential benefits from federating, and their logic, follow.

\subsection{Military Security}

A federal union is better able to defend itself than a confederation or looser alliance of states. The strength that comes from an expanded territory and resources, as well as the improved coordination of effort, makes members of the federal union more secure against foreign invasion than they are on their own (the Federalist; Riker 1964; Ostrom 1971). 


\subsection{Efficiency and Innovation}

This category includes economic benefits. Some compare federalism to a unitary state, arguing that decentralization brings benefits. In the fiscal federalism literature, the existence of two levels of government mean that taxation and expenditure policy may be efficiently distributed to maximize total utility (e.g. Musgrave 1997, Oates 1999). In the market-preserving federalism literature, decentralization and fragmenting authority enables a state to credibly commit not to expropriate all rents, when coupled with other conditions, such as a decentralization of fiscal control and hard budget constraints (Weingast 1995, Rodden and Rose-Ackerman 1997, Qian and Weingast 1997, Rodden and Wibbels 2002). Also, there may be benefits from lower government policy experimentation (Kollman et al. 2000); these may be economic in nature - welfare policy, taxation schemes - but often are not, directly, as with education or health care. At the same time, federalism is more centralized than a confederacy, and centralized regulation of trade permits a polity to enjoy the benefits of a common market (e.g. the Federalist).

\subsection{Effective Representation}

Madison praised federalism for its potential to improve the overall quality of representation over what was present in the state legislatures prior to federation, bolstering the feasibility of democracy (the Federalist, Elazar 1987, Ostrom 1991), Other benefits of federalism cite the value of decentralization: it may more effectively manage heterogeneous populations; distributing authority at lower levels may serve as a pressure valve, releasing ethnic tensions (the Federalist, Horowitz 1985, Stepan 1999). In the fiscal federalism literature, decentralization permits citizens to elect politicians who will tailor policy to meet local preferences or to move to states that better match their interests (Tiebout 1956, Inman and Rubinfeld 1992, Peterson 1995, Donahue 1997, Oates 1999).

Most federations are established for multiple reasons. In the Federalist, Hamilton, Madison, and Jay allude to the unions potential to make the states more secure against foreign invasion, to improve the economy through establishment of a common market, to minimize the incidence and consequences of skirmishes between the states, and (particularly Madison), to improve the quality of representative democracy.

A third and fourth reason for federating should be mentioned. First, some federations were established or encouraged by a colonial power with the aim of maintaining dependence, a sort of divide-and-conquer strategy. A fifth objective comes from the political economy of fiscal federalism literature (see especially Crémer and Palfrey 1999, 2002 and Hafer and Landa 2004). There are conditions where a majority would prefer federation to either confederation (no federal tax rate) or centralization (no regional tax). However, one must note that these results really concern the divide-the-dollar potential of federalism: that is, how one might divide the federal spoils. Given that federalism is an institutional arrangement, and that 
institutions create winners and losers, some will prefer federalism - even a majority - if it allows them to take advantage of the minority. This advantage of federalism over unitary or completely decentralized governance does not emphasize federalism's potential to increase total utility; it is a calculation based upon the utility of single agents. The redistributive aspects of federalism are very real, but are largely a problem of federalism, not a virtue (Filippov et al. 2004). Neither of these reasons are selections that a public would make behind the veil of ignorance; that is, in both cases, federalism is adopted to advantage some over others.

\section{Federalism as a Public Good Provision Problem}

In order to prescribe an institutional remedy, or even to understand how institutions might affect the performance of federations, it is important first to develop a thesis about what causes federations to perform better or worse. The thesis I describe may be summarized as follows: opportunistic behavior by the member governments is a destructive but natural tendency created by the decentralized structure, and therefore inherent to all federations. Opportunism is a behavior somewhat the opposite of "federal practice," which, although undefined in the literature, seems to mean a cooperation between governments that comes from the respect for the terms of the federal constitution, treating it like it is a covenant. While we cannot hope that federal practice will emerge spontaneously, institutions can affect it, by converting incentives to behave opportunistically into a motivation to cooperate. However, resolving the opportunism problem in federalism is more complicated than the textbook case of collective action. No single institution is sufficient. A successful federation depends upon a system of complementary institutions.

Through a series of eight claims, I connect federalism to the public good provision literature, with the objective of building a framework for considering how institutions can improve the robustness of federalism.

Claim 1: Federations have two basic problems: production and allocation.

Federations are established to take advantage of one or more of the potential benefits of federalism: military security, efficiency \& innovation, or political representation. Each of these benefits demands a coordinated effort to produce, and what is produced may be enjoyed by all members of the federation. A thriving federation generates further, divisible benefits.

Federations must solve the problem of production of their public goods and determine an equitable allocation of the divisible goods satisfactory to all members. Therefore, it is useful to speak of a federation's productive efficiency, the size of the pie, and allocative efficiency, how the pie is split. Changes in allocative efficiency are necessarily political. Redistribution means that some will do better while others are worse off. In contrast, all else equal, reductions in productive efficiency are unambiguous. A smaller pie is worse for everyone. 
Claim 2: Federalism's decentralized structure creates incentives for member governments to behave opportunistically.

We focus on the activity of member governments: the federal and state governments that comprise the federation. Because of the second criterion defining a federation, these member governments are accountable to their constituents. We assume that the elected officials within these governments are office-seeking and electoral accountability motivates them. This constituent-interest induces elected officials to generate policy that pleases their constituents; they focus on the allocative issues in federalism (Filippov et al. 2004), even if it reduces total utility (Bednar 2006).

The allocative focus will cause them to compete with other governments. Elected officials put the interests of their own constituents above the whole nation; in doing so, they will try to create policy that advantages their voters. At times, this will cause them to either skirt the existing federal distribution of power, or even readjust it, as they exercise power that is not theirs. (Claim 5 describes these actions in more detail.) We identify this behavior as opportunism. Notice that opportunism does not imply that officials are rent-seeking or wish to expand the size or power of government (Levinson 2005); here we assume that they are pure office-seekers, and opportunism is a behavioral product of this objective.

If a federation shows no sign of competitiveness between states and the federal government, then the second criteria of the definition of federalism may be compromised: the center has been able to accrue an excess of power, and the peripheral states are puppets of its authority. Often, this circumstance coincides with the demise of the democratic process, as in Mexico and the USSR. In these cases, to improve the robustness of the federation would be to improve the performance of the democracy. By refocusing on federal performance, not practice, we see that opportunism is a natural part of the practice of federalism.

Claim 3: Opportunism reduces federalism's productive efficiency and exacerbates allocative problems.

There are three approaches to understanding how opportunism could cause a federation to fail in its performance: inefficient allocation of authority, inefficient allocation of goods, and inefficient production of goods.

First is the notion that the authority within the federation is not well allocated. In the fiscal federalism literature taxation and expenditure policy may be efficiently distributed between the federal and state governments to maximize total utility. While this literature is traditionally non-strategic, marriage of its insights to gametheoretic analysis of the incentives of the political players instructs us about the hazards of opportunism to the federations' performance. Because opportunism is intended to serve the electoral interests of a particular government, this new distribution of authority may not - and most often will not - improve the union's productive efficiency. Opportunism shifts the federal system to a less efficacious distribution of authority, reducing the total utility of the federation, and detracting from its performance. 
While fiscal federalism is concerned with the generation of goods, the second approach considers the distribution of any divisible good that the federation produces as a by-product of its success. Some recent federalism literature focuses exclusively on allocation as the reason for decentralization (Crémer and Palfrey 1996, 1999, 2002, Hafer and Landa 2004). A member government's evaluation of the allocation may be absolute or relative, and subsequent jealousy from the latter concerns much of the political science of federalism; we see it in Riker's (1964) concern for the integrity of the "federal bargain," echoed in Lemco (1991), Dixit and Londregan (1998), and Watts (1996), and probed in depth in Filippov et al. 2004. Efficient production mitigates output concerns. If the output evaluation is comparative, jealousy is minimized if the overall pie is bigger. But if the initial distribution is fair, then shifts to it that are not Pareto improving are opportunistic, and measures to prevent opportunism will consequently affect the distributive tension.

The second approach brings us squarely to the third: the incentives to produce, given that production involves self-sacrifice, which opportunists attempt to skirt. Each of the federalism objectives invites temptations to free ride. Although no state wants to be invaded by a foreign power, each state would prefer that others send money and troops to build a common defense. Although all would like to enjoy the productivity of the common market, each state would like to protect its own industries. Although the market-preserving federalism literature tells us that a decentralized economy is better able to commit to repayment of loans, and the studies of political culture teach us that a decentralized state may cool ethnic rivalries, federal governments are tempted to steal control from the states to serve their own interests. Federal performance becomes a problem of public good provision. If the member governments have a temptation to shirk on their responsibilities, then the public good may be underprovided, and federal performance will suffer.

Claim 4: Institutional trigger mechanisms control opportunistic tendencies. However, opportunism cannot be eliminated. Opportunism is inherent to a federation.

The public good provision problem is applied to a wide range of circumstances (e.g. Hardin 1968, Downs and Rocke 1995, Greif et al. 1994). The remedy is often institutional: either add incentives to boost the attractiveness of compliance (Olson 1965) or erect trigger mechanisms, institutions that react to perceived opportunism with a punishment, thereby making compliance in each participants self-interest (Bendor and Mookherjee 1987, Ostrom 1990, Calvert 1995). Even when action is not subject to perfect monitoring, institutions may be effective at reducing opportunism (Green and Porter 1984, Downs and Rocke 1995). Under most realistic circumstances ${ }^{4}$ no institutional mechanism can eliminate all opportunism (Bednar 2004a). Therefore, in any functioning federation, some opportunism will persist. In robust federations, this inherent opportunism is minimized to maximize the union's productivity. 


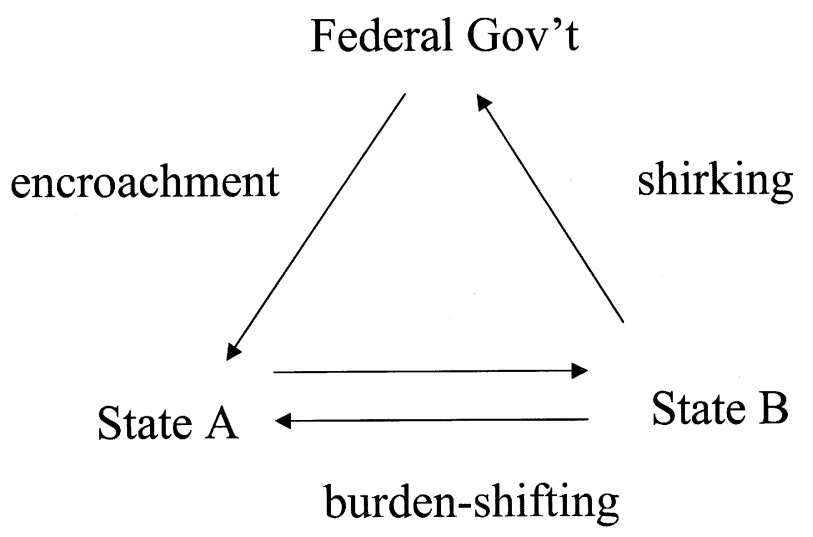

Figure 1. Types of Opportunism.

Claim 5: The complexity of the federal problem is greater than the classic public good provision problem because of the structural heterogeneity in the relationships between the governing agents.

Federalism has two types of government agents (federal and state), and the governments may take advantage of other governments in one of three ways (see Figure 1). State governments may try to shirk on their responsibilities to the federation: they may fail to implement federal policy or may take it upon themselves to enact policy that is normally in the federal domain rather than respect the division of powers. States may also shift the burden of making the union work onto the shoulders (and economies) of other states, for example by creating barriers to trade between the states, or affecting the mobility of citizens across state borders. Federal governments may centralize, encroaching upon the jurisdictions of the states, or decentralize to shift burdens away from the center.

Again, it is important to note that the elected officials who determine the governments' actions do not set out to alter the distribution of authority, at least not generally. Opportunism emerges as a consequence of their constituent service, as a result of their focus on allocation of goods rather than on the overall productive efficiency of the union.

To frame the federal problem as a single collective action problem grossly simplifies what is instead an interconnected web of collective action problems. Failure to control opportunism along one edge can lead to problems along another. The Federal Problem is not a single public good problem, but a collection of them. To argue that the complex interactions between member states, between the central government and the states, and among the institutions that mediate those interactions such as courts, party systems, bicameral legislatures, and constitutions can be explained by the same model that captures the grazing of sheep on a common field seems and is a stretch. Overgrazing sheep can be handled by any of a variety 
of single institutions. But in a federation, if an institutional remedy reduces shirking and burden-shifting, but is not able to contain encroachment, then the federation may become over-centralized as an unfettered federal government takes advantage of the states. Likewise, an institutional structure that is unable to reduce the degree of shirking may become, in Riker's (1964) terminology, over-peripheralized: the states will have great advantage over the federal government, and the benefits of coordinated action will be reduced. Partial coverage is insufficient: a successful institutional remedy will be balanced, addressing all three types of opportunism.

Claim 6: Institutions perform specific functions. No single institution is capable of managing all opportunism, but it may alleviate some form of opportunism.

Institutional safeguards of federalism come in three main forms: structural safeguards, political safeguards, and judicial safeguards. Structural safeguards are formal, generally constitutional, institutions, such as separation of powers in the federal government, a bicameral legislature, state involvement in federal decision-making, and the degree of centralization of the military (e.g. the Federalist). Structural safeguards generally constrain the federal government from encroaching upon the states, but have little potential to affect state behavior, although a nationalized military force may prevent shirking and burden-shifting.

Political safeguards, by contrast, are informal institutions that emerge as a consequence of formal institutions, such as the electoral law. The party system is the most salient example of a political safeguard. The party systems effect depends upon its organization and character: a highly centralized party system will stifle state-initiated opportunism, while a decentralized party may reduce encroachment because the local concerns become vital to the electoral interests of central-level actors (Riker 1964, Lemco 1991, Ordeshook and Shvetsova 1995, Ordeshook 1996, Kramer 2000).

Filippov et al. (2004) develop a theory of the contributions that an integrated party system makes to the stability of a federation. Their concern is with solving the federal problem of allocation, not production, but the integrated party system may reduce opportunism in any of three ways: coordination, patience, and nationalized vision. First, again, it is the nature of the production problem that as the pie grows, everyone is better off because there is more to share, but each individual has an incentive to take just a bit more for himself. The party system, through its organizational structure, may aid the cooperation necessary to overcome the suspicion of others' defection; it may also be more efficient at punishing deviants from within the party, in a form of in-group policing. ${ }^{5}$ Second, another element that inhibits cooperation is impatience: the short interval between elections and the "what have you done for me lately?" attitude of retrospective voters causes many political officials to prioritize immediate gains over longer-term growth strategies. Here again the party system may help by sufficiently overlapping the generations of candidates within it to stretch out their strategic perspective and promote production. ${ }^{6}$ Finally the party 
system may be an engine that develops a nationalized set of priorities, shifting attention away from the localized concerns that contribute to rivalrous, counterproductive behavior. These contributions by the party system are hypothesized, not established in the literature, and it is easy to generate intuitive counterhypotheses that suggest that the party system might fail to shift attention from the allocation problem to production.

Finally, we consider the judiciary. While the judiciary is a formally specified institution, the effect of judicial safeguards depends upon the doctrine that the court develops from the tools given it within the constitution. Judicial safeguards evolve over the lifespan of the federation, and often, doctrinal evolution is path dependent. The appropriateness of judicial regulation of the distribution of powers within a federation has been debated (Choper 1977, Bednar and Eskridge 1995, Yoo 1997, Kramer 2000), Questions about its legitimacy in refereeing federalism disputes reduce its effectiveness. Although in the United States the Supreme Court has begun to limit the federal government's encroachments, for the most part, the judiciary's best capacity is in regulating burden-shifting between state governments, since it is often viewed as beholden to the central government. In Riker's words, it is a "handmaiden" to the executive (1964:103). It certainly isn't a complete solution to the federal problem of production.

Claim 7: Institutions are composed of political agents with preferences that may not coincide with maximization of the performance of the federation.

In order for any safeguard - structural, political, or judicial - to deter free riders and therefore encourage productivity, it must establish a threshold that when crossed, triggers a punishment. On paper, we can derive the efficient threshold and punishment combination which induces the maximal degree of compliance or cooperation possible, and minimizes shirking. But real safeguards are not designed by theorists. Rather than being the passionless, detached referees of theory, the safeguards are composed of people with ambitions, idiosyncrasies, and weaknesses. The real people behind the triggers may set the threshold and punishment for private reasons, pulling the mechanism away from optimality.

For example, in Claim 6 I indicated that it was arguable that parties would reduce the productivity of the union rather than augment it. The party's motivation is clear: get its candidates elected. Individual politicians within the party want to be reelected, or elected to higher office, or an economically secure position after they leave office. None of these goals necessarily puts them in a position of wanting to patrol the federation when it clashes with their own self-interest. Also, these goals may shift. Therefore, with any of the safeguards, the operation of the trigger may shift: the definition of what action will trigger a punitive response may change over time, and institutions may err.

Claim 8: Redundant functional coverage by uncorrelated institutions may cancel their errors (stochastic or incentive-based). 
We want to avoid pairing institutions that may fail for the same causes for two reasons:

1. Institutions are not failsafe. They may make errors. Whether run by computers or humans, software glitches or distracted minds may upset the institutional mechanism. If one fails to catch opportunism, this has no effect on the probability that the other does. Thus, if each institution missed opportunism with probability $p$, the probability that both miss opportunism would be a mere $p$-squared: say, one percent as opposed to $10 \%$. Imperfect institutions may be effective (Bednar 2004b), but less efficient.

2. Claim 7 reminds us of the political creatures that make up the institutions. With logic similar to that of stochastic errors, the system works best when the political biases, or incentive-based errors, are not correlated or are negatively correlated (Bendor 1985).

For example, the judiciary is a competent patrol of burden-shifting, but while it may prevent federal encroachment (Eskridge and Ferejohn 1994), its does so best when independent, which requires other institutions to fragment federal authority sufficiently that it is freed to intervene without fear of retribution. Also, the judiciary's ability to umpire shirking is often compromised by charges of bias if it is not independent, since shirking is a judgment about whether the state is acting properly or infringing upon the federal government's domain (e.g. Cairns 1971). In these cases, the judicial safeguard is more secure in the presence of another institutional mechanism with unrelated imperfections, such as incorporation of the states into federal decision-making.

Therefore, the institutional system will most consistently resist opportunism when there is redundancy in each function, and the institutions covering that function do not fail for the same reasons. Redundant institutional functions, motivated independently, better-more consistently — prevent opportunism, improving performance.

Claims 6, 7, and 8 lead us to the following definition of institutional complementarity:

Coverage. Institutions complement one another when they form a system that provides complete coverage for all types of opportunism.

Overlap. Institutions complement one another within the type of opportunism covered (multiple institutions on each).

Error correlation. Avoid positive correlation in the cause of institutional failure.

We conclude this section with the following thesis: A robust federation relies on a system of complementary institutions that operates on the governments to reduce the incidence of all three types of opportunism and alleviates their consequences, thereby boosting performance.

By redirecting focus from a single institution to an ecology of institutions, complementary according to their functional ability and what causes them to fail, we 
arrive at a new "new institutional" thesis of federal robustness. Notice that the theory suggests the inappropriateness of measuring the effect of the presence of any one institution. For example, suppose that one believed that an independent judiciary was crucial to the success of a federation. Without an institutional complement to control the center, its effectiveness at controlling the states will translate into a lop-sided effect, centralizing power. Judicial safeguards, absent a complement, need not correlate with an increase in performance. Therefore, rather than asking: "is an independent judiciary necessary for a successful federation?" or a similarly minded question, this theory generates hypotheses about the relationship between complementary institutions and federal performance.

The theory explained the connection between institutions and opportunism: federations, by their structural composition, are prone to opportunistic behavior by their member governments, and this opportunistic behavior hinders the performance of the federation, reducing its robustness. Institutions constrain opportunism and minimize its effects by altering the incentive structure within the federation. Institutions cause the federation to be federal in practice, as well as structure. Institutional complementarity is necessary for federal robustness.

\section{Alternative Diagnoses and Prescriptions}

This paper has focused on the public good aspects of federalism and therefore defined the problem of federal robustness as one of compliance, where remedies overcome the inherent free rider problem. Two alternative conceptions should be considered: electoral accountability and redistribution.

Federations have a problem with electoral accountability, despite the potential representational advantages of the multi-tiered structure. The problem arises because responsibility may be confused when two governments might both claim involvement in successful policies, or may try to point to the other level of government in cases of policy failure (e.g. Peterson 1995, Bednar 2004c). In Ostrom (1994: 92-97), the people are ultimately sovereign, and therefore federalism is sustained by the various governments' accountability to the voters, but voter expectation must be made by consensus, a tall order for a diverse society.

Scharpf identifies the redistribution problem as a critical factor that contributes to federal failure, and argues that in order for federations to be successful, they must move beyond destructive zero-sum bargaining between subunits, and instead focus on potential positive sum gains from cooperation. Filippov et al. (2004)

The framing of the problem naturally determines the institutional prescription. If the focus is on redistribution, institutions that alleviate inefficient rivalry are highlighted, such as Filippov et al.'s integrated party system. The court may helpfully intervene in redistributional issues when the constitution contains substantive rights such as South Africa's constitutional promise of a minimal standard of living (Sunstein 2001). Juridical remedies do not make sense in constitutions that are largely procedural, such as the United States'; the court has no manifesto to adjudicate 
intergovernmental disputes over the distribution of divisible goods. They may affect distribution indirectly: for example, in rulings about school adequacy or minority rights likely affects federal monetary flow, and if the need is not spread uniformly across the states, the court's decision will benefit some states more than others. But this intervention is indirect and as likely to stir up distributional tension as quell it. Therefore, if one defines redistribution to be the primary problem of federalism, institutions so useful to compliance, such as courts, would have no natural place in the theory.

Solving the allocative problem is not the same as shifting attention from allocation to production. The former is a search for a distribution of divisible goods that satisfies all so that the federation is not threatened by secession. The latter transformation is a way of making the value of contribution to public goods great enough that is subsumes the temptation to fail to contribute or to focus attention purely on laying claim to as many divisible goods as possible. Both problems-equitable division and efficient production-need to be solved.

\section{Conclusion}

This paper has argued that federalism is a public good: that is, it is capable of generating political, economic, and military benefits and in fact is adopted to pursue these meta-products. However, due to the indivisible nature of these goods, their production is burdened by an inescapable free rider problem. Therefore, much of the concern in institutional design is about structuring the incentives in order to overcome the tendency by the member governments within the federation to take advantage of the system, and instead to contribute to its robust performance.

No unique institutional remedy exists to solve federalism's problem of production, and no single institution is capable of resolving all manifestations of federal opportunism. A robust federation will rely on complementary institutions that support one another's coverage and insure against one another's failure.

\section{Notes}

1. For useful feedback, I thank seminar participants at Washington University, Duke, and Michigan.

2. For example, Riker's (1987:101) definition is often used, despite its ambiguity: "a political organization in which the activities of government are divided between regional governments and a central government in such a way that each kind of government has some activities on which it makes final decisions."

3. Most measured success by longevity, or current existence (Riker 1964, Franck 1968, Dikshit 1975, Hicks 1978, Filippov et al. 2004). Lemco (1991) codes all federations as "stable," "partly stable," or "not stable/ended." With such a stark coding, it is only natural that there would be unfortunate examples of quick reversals in fortune that undermine the credibility of the analysis: shortly after 
Lemco's book was published, Czechoslovakia and the USSR "failed," despite their "stable" coding. Canada, coded as "unstable," has remained intact.

4. Given two conditions, (1) imperfect information and either (2a) declining marginal utility from opportunism or (2b) increasing probability of detection as opportunism increases, then by Bednar (2004a), the optimal (efficient) trigger mechanism will minimize, but not eliminate, opportunism.

5. See a related example in Fearon and Laitin (1996).

6. In Diermeier (1995), the institutional structure of Congress generates overlapping generations of legislators, enabling coordination despite lawmakers' short time horizons.

\section{References}

Bednar, J. (2004a) "Is Full Compliance Possible? Conditions for Shirking with Imperfect Monitoring and Continuous Action Spaces." University of Michigan manuscript, under review.

Bednar J, (2004b) "Judicial Predictability and Federal Stability: Strategic Consequences of Institutional Imperfection." Journal of Theoretical Politics 16(4): 423-46.

Bednar, J. (2006) "Credit Assignment and Federal Encroachment." Supreme Court Economic Review, forthcoming.

Bednar J. and Eskridge, W. N. Jr. (1995) "Steadying the Court's 'Unsteady Path': A Theory of Judicial Enforcement of Federalism." Southern California Law Review 68: 1447-91.

Beer, S.H. (1993) To Make a Nation: The Rediscovery of American Federalism. Cambridge, MA: Belknap Press.

Bendor J, (1985) Parallel Systems: Redundancy in Government. Berkeley: University of California Press.

Bendor, J. B. and Mobkherjee, D. (1987) "Institutional Structure and the Logic of Ongoing Collective Action." American Political Science Review 81(1): 129-54.

Cairns, A. C. (1971) "The Judicial Committee and its Critics." Canadian Journal of Political Science 4(Sep): 301-44.

Calvert, R. L. (1995) "Rational Actors, Equilibrium, and Social Institutions” In: Knight, J., and Sened, I. (eds.)Explaining Social Institutions. Ann Arbor: University of Michigan Press.

Choper, J. (1977) "The Scope of National Power vis-a-vis the States: The Dispensability of Judicial Review." Yale Law Journal 86: 1552-1621.

Crémer, J. and Palfrey, T. R. (1996) "In or Out? Centralization by Marjority Vote." European Economic Review 40: 43-60.

Crémer, J. and Palfrey, T. R. (1999) "Political Confederation." American Political Science Review 93(1): 69-83.

Crémer, J. and Palfrey, T. R. (2002). "An Equilibrium Model of Federal Mandates." Caltech manuscript.

Diermeier, D. (1995) "Commitment, Deference, and Legislative Institutions." American Political Science Review 89(2): 344-55.

Dikshit, R. D. (1975) The Political Geography of Federalism: An Inquiry into Origins and Stability. New York: John Wiley \& Sons.

Dixit, A. and Londregan, J. (1998) "Fiscal Federation and Redistriibutive Politics." Journal of Public Economics 68(2): 153-180.

Donahue, J. D. (1997) “Tiebout? Or Not Tiebout? The Market Metaphor and America's Devolution Debate." Journal of Economic Perspectives 11(4): 73-81.

Downs, G. W. and Rocke, D. M. (1995) Optimal Imperfection? Domestic Uncertainty and Institutions in International Relations. Princeton, NJ: Princeton University Press.

Elazar, D. J. (1987) Exploring Federalism. Tuscaloosa: University of Alabama Press.

Eskridge, W. N. and Ferejohn, J. (1994) "The Elastic Commerce Clause." Vanderbilt Law Review 47(Oct): $1355-1400$.

Fearon, J. D. and Laitin, D. D. (1996) "Explaining Interethnic Cooperation." American Political Science Review 90(4): 715-35. 
Filippov, M., Ordeshook, P. C. and Shvetsova, O. (2004) Designing Federalism: A Theory of SelfSustainable Federal Institutions. Cambridge, UK: Cambridge University Press.

Franck, T. M. (ed.) (1968) Why Federations Fail: An Inquiry into the Requisites for Successful Federalism. New York: New York University Press.

Green, E. J. and Porter, R. H. (1984) "Noncooperative Collusion under Imperfect Information." Econometrica 52(1): 87-100.

Greif, A., Milgrom, P., and Weingast, B. R. (1994) "Coordination, Commitment, and Enforcement: The Case of the Merchant Guild." Journal of Political Economy 102(4): 745-76.

Hafer, C. and Landa. D. (2004). "Public Goods and Federal Systems." New York University manuscript. Hardin, G. (1968) "The Tragedy of the Commons." Science 162: 1243-8.

Hardin, R. (1989) "Why A Constitution?" In: Grofman, B., and Whitman, D. (eds.)The Federalist Papers and the New Institutionalism. New York: Agathon.

Hicks, U. K. (1978) Federalism: Failure and Success, a Comparative Study. New York: Oxford University Press.

Horowitz, D. L. (1985) Ethnic Groups in Conflict. Berkeley: University of California Press.

Inman, R. and Rubinfeld, D. (1992) "Fiscal Federalism in Europe: Lessons from the United States Experience." European Economic Review 36(2-3): 654-60.

Jen, E. (2002). "Stable or Robust: Whats the Difference?" Santa Fe Institute Working Paper 02-12-069.

Kollman, K., Miller, J. H. and Page, S. E. (2000) "Decentralization and the Search for Policy Solutions." Journal of Law, Economics, and Organization 16(1): 102-28.

Kramer, L. D. (2000) "Putting the Politics Back into the Political Safeguards of Federalism." Columbia Law Review 100: 215-93.

Lemco, J. (1991) Political Stability in Federal Governments. New York: Praeger Publishers.

Levinson, D. 2005 (forthcoming). "Empire-Building Government in Constitutional Law." Harvard Law Review 118: 915-972.

Musgrave, R. A. (1997) "Devolution, Grants, and Fiscal Competition." Journal of Economic Perspectives 11(4): $65-72$.

Oates, W. (1999) "An Essay on Fiscal Federalism.” Journal of Economic Literature 37(3): 1120-49.

Olson, M. (1965) The Logic of Collective Action: Public Goods and the Theory of Groups. Cambridge, MA: Harvard University Press.

Ordeshook, P. C. (1996) “Russias Party System: Is Russian Federalism Viable?"” Post-Soviet Affairs 12(3): 145-217.

Ordeshook, P. C. and Shvetsova, O. (1995) "If Madison and Hamilton Were Merely Lucky, What Hope Is There for Russian Federalism?." Constitutional Political Economy 6(2): 107-26.

Ostrom, E. (1990) Governing the Commons: The Evolution of Institutions for Collective Action. New York: Cambridge University Press.

Ostrom, V. (1971) The Political Theory of a Compound Republic. Lincoln: University of Nebraska Press. Ostrom, V. (1991) The Meaning of American Federalism: Constituting a Self-Governing Society. San Francisco: Institute for Contemporary Studies.

Peterson, P. E. (1981) City Limits. Chicago: University of Chicago Press.

Peterson, P. E. (1995) The Price of Federalism. Washington DC: Brookings.

Qian, Y., and Weingast, B. R. (1997) "Federalism as a Commitment to Preserving Market Incentives." Journal of Economic Perspectives 11(4): 83-92.

Riker, W. H. (1964) Federalism: Origin, Operation, Significance. Boston: Little, Brown and Company.

Riker, W. H. (1987) The Development of American Federalism. Boston: Kluwer Academic Publishers.

Rodden, J. and Rose-Ackerman, S. (1997) "Does Federalism Preserve Markets?." Virginia Law Review 83(7): $1521-72$.

Rodden, J. and Wibbels, E. (2002) "Beyond the Fiction of Federalism: Macroeconomic Management in Multitiered Systems." World Politics 54: 494-531.

Stepan, A. (1999) "Federalism and Democracy: Beyond the U.S. Model." Journal of Democracy 10(4): $19-33$. 
Sunstein, C. R. (2001) "Designing Democracy: What Constitutions Do." New York: Oxford University Press.

Tiebout, C. M. (1956) "A Pure Theory of Local Expenditures." Journal of Political Economy 64(5): $416-24$.

Watts, R. (1996) Comparing Federal Systems in the 1990s. Kingston, ON: Queens University, Institute of Intergovernmental Relations.

Weingast, B. R. (1995) "The Economic Role of Political Institutions: Market-Preserving Federalism and Economic Growth." Journal of Law, Economics, and Organization 11: 1-31.

Yoo, J. C. (1997) "The Judicial Safeguards of Federalism." Southern California Law Review 70: 13111405. 